\title{
Environmental Protection toward the Globalization Era
}

\author{
Flora Pricilla Kalalo \\ Faculty of Law, University Sam Ratulangi, Manado, Indonesia \\ Email: flora_florakalalo@yahoo.com
}

Received: June 5, 2015 Accepted: June 29, 2015

doi:10.5296/emsd.v4i2.7744 URL: http://dx.doi.org/10.5296/emsd.v4i2.7744

\begin{abstract}
The Environment greatly affects the global life in which humans become part of it. Good environment and healthy is a state that is highly desired by everyone. However, it is inevitable that the current global situation is getting worse over time. Globalization activities that occur between one country to another country for the sake of economic progress triggers environmental problems, such as the opening of new lands for economic activity continues to be done so that the green areas in the world is declining. Indonesia, which is one-on-one countries that are the lungs of the world are facing the same thing. Indonesia also had to adapt to be able to engage actively promote economic and perform construction but without damaging the existing environment. Therefore the development of environmentally sound with the principle of sustainable development as set out in the rules should be the cornerstone of national Indonesia in carrying out development in Indonesia.
\end{abstract}

Keyword: Environment, Globalization, Sustainable Development

\section{Introduction}

The environment is a very important aspect that cannot be separated from human life. The environment is which the human being it is always changing with the times. In the era of globalization where economic progress and development is a very important thing makes the environment become victims due to reduced green lands for the sake of development activities in order for economic progress. So that development and environment have been seen as two things are always contradictory. The problem is, the construction of which is pursued through industrialization often creates problems in the environmental field to cause destruction and environmental pollution, such as that delivered by Sony K. (2010) that humans are the main cause of environmental degradation. Efforts to prevent the contradiction between development and environmental preservation is likely to find, with the argument that combining these two interests will lead to high-cost industries. While it demands an 
acceleration of industrialization as a pursuit of pace from developed countries cannot be avoided.

Political development in this context cannot escape to stand up for in the industrial sector, because this sector is excellent and the backbone is expected to catch up with the third world countries from developed countries, but aims to improve the public welfare. Development is often defined as the implementation of certain changes to the society. Often, too, confirmed that the construction is against human nature. The general sense has a dual nature. On the one hand it confirms the orientation of development, but on the other hand ignoring reality. In fact, not just the changes to the development of a society, but is also changes to the environment. It will be serious environmental problems that the UN felt the need to set up an agency, UNEP (United Nations Environmental Programmed) in charge of that area who served in that field. The agency is still not enough, and the UN has been followed by the establishment of a special body which was given the task of dealing with development and the environment (World Commission on Environmental and Development - WCED), which also has a group of experts tasked with reviewing the legal principles that can ensure and protect global development programs, WCED, Expert Group on Environmental Law.

These symptoms indicate the development as a terminology which contains a double aspect, as well as change the terms included in it. Change is ambiguous term, can meaningful progress (progress) and also a significant setback (Regress). In spite of more development terminology is given a positive connotation (progress), but also development potential as a setback because (Regress) (H.R. D. Naja, 2010).

Environmental problems in the developed countries are the core related to the results and consequences of economic progress, so the idea that developed in the environmental field applies especially to respond to the problems encountered in the typical developed countries, but less significant for countries emerging. Many times, the environmentalists claim that free trade would be the cause of the destruction or the destruction of the environment, because of the emphasis on free trade is as small as possible to eliminate various provisions or policies that would hamper trade between countries as part of the impact of globalization which reduce space the scope or the distance between one country with another country. Inversely proportional to the environmentalists, advocates of free trade claim that the opinion of the environmentalists is a bigotry that did not make sense or an excessive protection measures, since many provisions that would hamper the development of an international trade.

Need to be discussed as to whether it is true the provisions of the General Agreement on Tariffs and Trade (hereinafter GATT) will interfere with the protection of the environment and what are the provisions of Indonesia as one of the countries that ratified the treaty liberalizing world trade (The Final Act embodying the Results of the Uruguay Round of Multilateral Trade Negotiations). Or conversely, whether the provisions aimed at protecting some aspects of the environment actually become an obstacle in implementing free trade.

\section{Analysis}

Development could have a negative impact on the environment as a result of the negative impact this can be crossed state borders. Various developments activities cannot be avoided by 
anyone, so then do a variety of measures that can reduce the negative consequences are reflected in various international agreements. One is the international meeting in Rio de Janeiro conference better known as the Earth Summit agreed on one principle tahun1992yang development, namely sustainable development or in Indonesia is defined as the principle of sustainable development or environmentally sustainable development. Based on this principle expected that each offender activity, including the government in each country, preventive action so that its activities do not negatively impact the environment.

This principle has historically, has emerged since the 19th century, especially in the various regulations relating to the use of biological resources, especially fish. For example, the Convention between France and Great Britain Relative to Fisheries in 1867, or the Convention establishing Union from Regulations Concerning Fishing in the Rhine between Constance and Basle, 1869. It contains various provisions borders against excessive utilization of fish, both in rivers, lakes or the territorial sea, Usually with restrictions on the amount of fish caught or boundaries arrest. Until now in some countries, like the United States, there is no necessity to ask for permission if someone would fish.

The principle of sustainable development Sustainable Development or explicitly raised in the report of the Brundtland Commission in 1987 which is defined as: local development that meets the needs of the present without compromising the ability of future generations to meet Reviews their own needs. This understanding is used as a strategy that means improving the quality of human life while living within carrying capacity of supporting ecosystems.

That is, with this principle expected that the man should be careful in maintaining the quality of life for the ecosystem where humans dwell have limited capabilities. Therefore, if used excessively, it will result in negative impacts on human habitat itself. Calculation limited ability (carrying capacity) of each species and ecosystems is calculated based on the calculation of the ecological, as well as the course followed by economic calculation. Sustainable development is environmentally conscious and planned effort that integrates the environment including the resources into the development process to ensure the ability, well-being and quality of life of present and future generations to come.

This principle is further elaborated into some specific principles, including the precautionary principle (the precautionary principle), polluter pays principle (polluter pays principle), duty to cooperate (obligation to cooperate), and equal access and non-discrimination ( equal access and no discrimination among all stake holders). The four principles are in general appeared in a variety of conditions, policies, and programs related to environmental management. For example, the precautionary principle appears in the policy Conservation of Biological Diversity (both in the Convention on Biodiversity in 1992 and in Law No. 5 of 1990 on Conservation of Natural Resources and the ecosystem), or the obligation of Environmental Impact Analysis (EIA) in certain business activities (Article 22-33 of Law No. 32 of 2009 on the Protection and Management of the Environment (UUPPLH). Policy aims to benefit a variety of conservation of natural resources is not to reduce the potential for these resources. This policy was subsequently raised by various provisions, such as restrictions or bans fishing area catch of special fish (within the meaning of the scarcity of certain species of fish). Policies 


\section{Mll Macrothink}

Environmental Impact Assessment (EIA) is also intended to make certain every business will always be cautious in carrying out its activities so that the raw materials used not depleted or even become damaged. In addition, businesses should also assess the actions taken in the event of negative impact of its activities.

Sustainable Development principles accompanied by some principle still has not reached adequate results. This is evident from the various activities that indicate increasing damage and or environmental pollution, such as the opening of new lands that are not accompanied by good environmental management. Reduced variety of biological resources (or more breadth of biodiversity) that is could be utilized. The question is whether the era of free trade can help the destination principle of Sustainable Development (SD), or even reverse this will further aggravate the situation.

The basic principles of environmentally sustainable development or can be added as well, in addition to those previously mentioned as follows:

I. 1). Equity and Justice Society.

2). Distribution.

3). Equalization. Economic equalization balanced.

II. Valuing diversity.

III. The use of integrative between man and nature.

IV. Long-term perspective, the economic, ecological, social and cultural.

The basic system or environmentally sustainable development are as follows:

1. Ecological.

2. Sustainable economic, macro and filed.

3. Socio-cultural, population stability, fulfillment of basic human needs, encouraging the participation of local communities, demonstrating the public's decision.

4. Sustainable politics.

5. Sustainable security defense.

Development activities that are not accompanied by the Control and Management Environmentalists (PPLH) it which resulted in a disaster on human goodness. Thus, the concept of monitoring, management and implementation of environmental legislation is key to the achievement of environmental sustainability.

Sustainable development requires a relationship between the central government, provincial, and district / municipality in environmental management is no longer based on hierarchy, but based on the synergy between the government and also between government and the private sector, universities, non-governmental organizations (NGOs), community organizations, and the wider community. This means, the implementation of regional autonomy in environmental management is expected to grow a new commitment of all parties to realize that good environmental management, in which all interested parties can form a strategic alliance in environmental management. As presented by Assiddiqie, J. (2010) namely Indonesia as one of the heart and lungs of the world, often expected to be a pioneer and driving force of the creation of sustainability and environmental sustainability. For it is 
absolutely necessary to increase environmental awareness culture in all aspects of life in society, nation, and state. So that all actions and policies are adopted will always pay attention to all aspects related to the environment.

\subsection{Efforts Environmental Protection in the Era of Free Trade}

a. The principle of the Free Trade Era

The principles of the free trade system are: Most Favored Nation, National Treatment, and Transparency. Based on these principles is expected to trade between countries can be carried out without discrimination, more competitive, the reduction of trade barriers made in negotiations, and at the same time can also provide benefits to the less developed countries. Results of the negotiations appear in a variety of international regulations, such as the Trade Related Aspects of Intellectual Property Rights (TRIPS), Trade Related Investment Measures (TRIM) or the General Agreement on Trade of Services (GATS) which must be complied with by the countries that ratified, including Indonesia. Trade and the environment have been recognized by countries that do deal General Agreement of Tariffs and Trade (GATT) in 1947, at least this is reflected in Article 20 of the General Agreement on Tariffs and Trade (GATT). The article states that exceptions can be made by the state of the parties to enforce the principles and provisions of this agreement, among others, relating to actions for:

a. protect the health and life of humans, plants and animals;

b. conserving natural resources cannot be renewed.

Agreement on the protection of the above confirmed in the Agreement on the Application of Sanitary and Phyto-sanitary Measures as one of the results of the development round of negotiations in Uruguay. This Agreement contains the assertion that the member countries (World Trade Organization (WTO) must perform various actions required to protect the health or life, whether human, animal or plants. Further, should be explained referring to the international standards created by certain international organizations. The problem is, if all countries, especially developing countries can undertake appropriate protection standards required, or even many time it became one of the non-tariff barriers on the grounds, for example health reasons and in fact can be said to be one of the barriers in trade. ,

Other approvals relating to the protection of the above problems are also present in agricultural agreement (Agreement on Agriculture). Listed in the opening is the state agreements may take action that is needed for protection against the availability of agricultural products world. From the environmental side, this agreement reflects the awareness of the limited capabilities of each type of plants and animals (including ecosystems).

This protection also explicitly agreed to in various international treaties relating to the environment, such as the Convention on International Trade in Endangered Species (CITES). Various types of plants and animals listed in the Convention may not be traded or at least there is a barrier to trade them. That is, in this case a free trade can be regarded as one of the non-tariff barriers.

The agreement on Trade Related Aspects of Intellectual Property Rights (TRIPs), special 
problem patent, is also one reflection of environmental protection. At this provision stated that the government of a country can refuse a patent application if the product will actually threaten the life of living creatures in this world. Even in practice, it is not easy to do, because to know whether a product to be patented would be life threatening, requires in-depth knowledge. Such this knowledge not necessarily shared by all countries (members). Therefore, could result in the rejection of a patent application can be claimed by the country under the pretext of trade barriers.

\section{b. Environmental Protection Efforts}

Twenty years after a conference in Stockholm in 1972, the Earth Summit held meetings which resulted in various international agreements, whether it is a hard law and soft law. One such agreement is the various action plans to face the 21 st century. The action plan in development to keep pace with the ability of the environment, better known as Agenda 21, also think of the problems associated with the trade. The countries agreed to provide support in the achievement of the Development goal oriented environment. One way to measure in this objective is:

a. promoting sustainable development through trade liberalization;

b. making trade and environment mutually supportive;

c. providing adequate financial resources to developing countries and dealing with international debt;

d. encouraging macroeconomic policies conducive to environment and development.

This thinking is understandable because a lot of countries participants of the conference in Rio was once a member of the World Trade Organization (WTO). Obviously a lot of thought to them, especially the developed countries, which pushed the deal a trading system, adopted by them at a meeting in Rio this. Even still, the basic principle is sustainable development.

Four points above form the basis of the Action Plan for Social and Economic Dimensions, which consists of four (4) courses; namely:

a. Sustainable promoting development through trade;

b. Making trade and environment mutually supportive;

c. Providing adequate financial resources to developing countries; and

d. Encouraging economic policies conducive to sustainable development.

Explanations of the fourth program are as follows:

a. The basis of the first program is to make the multilateral trading system that is open, equal, safe, non-discriminatory and predictable (predictable). That is, the countries agreed to promote the principle sustainable development through trade should assume that all countries (involved in international trade) is equal to the things that if it can inhibit the trading system can be discussed without any particular country that can put pressure.

b. The basis of the program B is that an open trading system that will enable the use and location of resources more efficient.

c. Financing economically be important for developing countries, due to the achievement of environmentally sound development costs. Indonesia as one of the countries that approved 
the Agenda 21 also carry out and can be seen from the emergence of the instructions of national strategies to achieve sustainable development (or in Indonesia used definition of sustainable development), called Agenda 21, Indonesia. In addition to these specific strategies, efforts to protect the environment will be studied from several conditions and applicable policies or programs in Indonesia.

\subsection{Strategy Indonesia toward Free Trade}

Office of the State Minister of Environment of Indonesia in 1997 published the Action Plan or Agenda 21 Indonesia by paying attention to what is stated in Agenda 21. The focus of this action plan is on community service, waste management (including waste B3), the management of land resources, and management of resources natural resources (SDA). This action plan was in tune with what is stipulated in Law No. 32 of 2009 even in this rule has been mentioned about the air environment, although not specifically regulated further.

Action Plan relating to the global trading system are the focus of the first. Coinciding with the publication of this action plan, Indonesia has entered the Long-Term Development of 25 (twenty five) year 2 (PJP II). This challenge spur Indonesia looking for targets that can face the global trading system that forces the domestic trade of a country to be able to compete with other countries. However, it should not be overlooked is the use of a national strategy in the trade that also pay attention to the principles of sustainable development. This principle is used as the basis of various policies, programs and provisions to prevent the decline of natural resources which are widely used as raw material for various economic activities.

Indonesia is following the global trading system with the aim to become one of the newly industrialized countries in Asia Pacific region. Therefore, Indonesia must perform transformations in the economy by changing the priorities of development of the agricultural sector into industry sector supported by the agricultural sector. However, it must be remembered, the consequence of increasing economic growth is likely to have a negative impact on the environment (such as increasing pollution). To prevent this, Indonesia in-corporate environmental strategies into economic development and establishes have three (3) priorities, namely: the principle of pollution prevention, pollution control and remediation. The strategic are:

1. Development of economic approach in the management of natural resources (SDA) and the environment;

2. Development of pollution prevention approach (waste minimization and cleaner production); and

3. Development of the economic balance of the system, natural resources (SDA), and the environment.

Equity, increasing the role of local and community participation, competitiveness and also ensure the beneficial sustainability of natural resources (SDA) and the environment. Economic development is indeed priority community-based economy. However, in one of its programs on the development of the industry is still competitive. This is due to the realization 
that Indonesia has ratified various global trade deal must still perform various actions in the face of tough competition.

The second strategy used to reduce waste products while reducing waste and B3 (hazardous and toxic materials) will be relatively neutral, so that when discharged into the environment is not harmful to people and the environment surrounding the activity carried out. Based on this strategy are also expected volumes of waste or garbage resulting from an activity will be reduced. Though in reality, the problem of waste into one is the crucial issues that must be addressed by governments, especially in big cities. Moreover, that is also being actively done is produce a clean product. That requires various studies in order to generate the appropriate technology and low cost. This strategy is also recognized as a superior strategy in controlling pollution than previous approaches that use end of pipe.

It is most needed in the third strategy is setting up an information system that integrates environmental and social dimensions into economic strategy. One of the activities that are needed in the global trading system is certified eco-label. Eco-label is a labeling on a product indicates that the product is already paying attention environmental rules so that products can be said to be environmentally friendly. This process starts from the selection of raw materials to produce a product activity. For example in the field of textile industry, this process has been started from raw materials (textiles and the use of chemicals), the transport of the raw materials to the plant, the process plant, waste management and garbage to the transport of these products to the consumer. In general, the eco-label certificates must be meet three (3) main criteria, namely: 1). sustainability of production; 2). ecology; and 3). socio-cultural.

The preservation of these products generally must meet two (2) categories, namely how the form of the product or use of the product and how the product is made. One example is the use of halogen bulbs that use less energy than ordinary light bulbs. Another example is the labeling of the furniture using wood raw material harvested with consideration of sustainability (do not use a lot of teak wood infancy decades).

Product sustainability must be considered whether a product is dangerous to human life and the environment or not. Certification eco-label can also show this aspect. For example, the label "CFC Free" can explain to consumers that the products using CFC materials harmful to the Earth's atmosphere because it will reduce or even eliminate the ozone layer serves to protect life on Earth's surface.

It is important in this labeling activities is the availability of adequate information and simple to explain about this product and also the process so that consumers have the knowledge to select the desired product. As well as for producers, labeling these activities will increase sales (certainly expected at affordable prices).

Eco-label has become an activity that is included in the world trading system. Through this certification, a product's country will be preferred because consumers residing in other countries can be confident that the product will not have a negative impact on the environment. There are various institutions, both internationals, regional and national levels who can give this certificate. For examples is the International Organization for 
Standardizations (ISO) 14000), Forest Steward Council (FSC), and international Tropical Timber Organizations (ITTO).

National Tertiary institutions are Eco-label Indonesia Institute (LEI). Institutions Eco-label Indonesia (LEI) which consists of 1994 is a nonprofit organization that aims to assist the Government of Indonesia in order to carry out its commitment to sustainable development or environmentally friendly development (especially when seen as the product) and in fact, it has become one certificate one count in the world trading system. This can also be seen as one of the non-tariff barriers to enter the global market.

First time Eco-label Indonesia Institute (LEI) to much provide eco-label certificates to various wood products (such as furniture) because in the world trade of Indonesian products are often rejected by other countries because they do not have a certificate of eco-label, as happened in the early 2003's. In addition to wood products, Indonesia is also facing constraints on other sectors, such as fish exports to the global market. The European Union has issued a new provision relating to the product sardines. Sardines are allowed to be labeled only from the type of sardenpilchardus. While sardine products from ASEAN, including Indonesia is of the type Sardinela longiceps and should not be labeled as canned fish.

The above examples, it shows that in the global trading system, labeling can be one of non-tariff barriers, particularly for developing countries. The argumentation developed countries is in order to preserve production (which became one of the criteria of eco-label certification). Therefore, Indonesia (forced) must perform various steps to anticipate these barriers. One of them is to perform various actions for efficient cultivation to marketing. In addition, Indonesian otherwise perform various lobby in order to produce quality standards relative mechanisms can take into account not only the interests of developed countries. However, it is also developing countries (including Indonesia). Another thing that is likely to do is make a provision requiring any businessmen (especially to export their products) to make certification eco-label not only the activities of voluntary / voluntary only.

\section{The Result}

International agreement stipulates that in implementing the system of free trade in this era of globalization, countries that run this system should pay attention to environmental protection efforts. Indonesian environmental protection refers to Law No. 32 Year 2009 on the Management and Protection of the Environment. Development and economic progress is inevitable, but in its implementation should pay attention to the development of environmentally sound by using the principles of sustainable development.

Trade and the environment have been recognized by countries that do deal General Agreement Tariffs and Trade (GATT) in 1947 so that in every action taken by the participating countries must be able to guarantee their agreement on the protection of the health and life of humans, plants, animals and conserving the natural resources that cannot be renewed.

Indonesia's strategy including free trade system is certified eco-label. This certification is intended for economic actors still consider the sustainability of natural resources that exist as 
well as a raw material for various business activities. Though in reality, this certification request can be considered as one of the non-tariff barriers for developing countries to export their products to developed countries.

In connection with efforts to protect the environment in the era of free trade, should be coupled with the environmental law enforcement that involves all levels of society in Indonesia and in the world.

\section{References}

Agenda 21 Indonesia. (1997). Kantor Menteri Negara Lingkungan Hidup dan UNDP.

Assiddiqie, J. (2010). Green Constitution (Nuansa Hijau Undang-Undang Dasar Negara Republik Indonesia Tahun 1945), Rajawali Press, Jakarta.

Birnie, P., \& Allan B. (1990). International Law and Environmental, Oxford University Press, New York.

Caring for the Earth: a Strategy for Sustainable Living, (1991). IUCN, UNEP \& WWF, Switzerland, October.

Djamin, D. (2007). Pengawasan \& Pelaksanaan Undang-undang Lingkungan Hidup Suatu Analisis Sosial, Yayasan Obor Indonesia, Jakarta,

Keraf, A. S. (2010). EtikaLingkunganHidup,Kompas Media Nusantara, Jakarta.

Naja, H.R.D. (2007). Bank Hijau Kebijakan Kredit yang Berwawasan Lingkungan,MedPress, Yogyakarta.

Nicholas, A. R. (ed.), (1993). AGENDA 21: Earth's Action Plan., IUCN. New York, Oceana Publications, Inc.

Siahaan, N. H. T. (2004). Hukum Lingkungan dan Ekologi Pembangunan Edisi Kedua, PT.Gelora Aksara Pratama, Jakarta.

Rasjidi, Lili., dan I. B. Wyasa P., (1993). Hukum Sebagai Suatu Sistem, First Edition, Remaja Rosdakarya, Bandung.

Rothery, B. (1995). ISO 14000, PT Pustaka Binaman Pressindo: Jakarta.

Sands, P. (1995). Principles of International Environmental Law, Manchester University Press, New York.

World Resource Institute, (1994). World Resources 1994-1995, Oxford University Press, 1994.

Utama, I M. Arya, (2004). Hukum Lingkungan, Sistem Hukum Perijinan Berwawasan Lingkungan untuk Pembangunan Berkelanjutan, Pustaka Sustra, Bandung.

Zaidun, M., (1995). Amdal Sebagai Piranti Efektif Bagi Upaya Pengendalian Pencemaran Industri (Jurnal Hukum Lingkungan), Tahun II No. 1, Jakarta : Indonesian Center For Environmental Law. 


\section{Macrothink \\ Environmental Management and Sustainable Development \\ ISSN 2164-7682 \\ 2015, Vol. 4, No. 2}

\section{Copyright Disclaimer}

Copyright for this article is retained by the author(s), with first publication rights granted to the journal.

This is an open-access article distributed under the terms and conditions of the Creative Commons Attribution license (http://creativecommons.org/licenses/by/3.0/). 